\title{
GLUT4 content decreases along with insulin resistance and high levels of inflammatory markers in rats with metabolic syndrome
}

\author{
Natalia M Leguisamo ${ }^{1}$, Alexandre M Lehnen ${ }^{1}$, Ubiratan F Machado ${ }^{2}$, Maristela M Okamoto ${ }^{2}$, Melissa M Markoski ${ }^{1}$,
} Graziela H Pinto ${ }^{1}$ and Beatriz D Schaan ${ }^{1,3^{*}}$

\begin{abstract}
Background: Metabolic syndrome is characterized by insulin resistance, which is closely related to GLUT4 content in insulin-sensitive tissues. Thus, we evaluated the GLUT4 expression, insulin resistance and inflammation, characteristics of the metabolic syndrome, in an experimental model.

Methods: Spontaneously hypertensive neonate rats (18/group) were treated with monosodium glutamate (MetS) during 9 days, and compared with Wistar-Kyoto (C) and saline-treated SHR (H). Blood pressure (BP) and lipid levels, C-reactive protein (CRP), interleukin 6 (IL-6), TNF-a and adiponectin were evaluated. GLUT4 protein was analysed in the heart, white adipose tissue and gastrocnemius. Studies were performed at 3 (3-mo), 6 (6-mo) and 9 (9-mo) months of age.
\end{abstract}

Results: MetS rats were more insulin resistant ( $p<0.001$, all ages) and had higher BP (3-mo: $p<0.001,6-m o$ : $p=0.001$, 9-mo: $p=0.015$ ) as compared to C. At 6 months, CRP, IL- 6 and TNF-a were higher ( $p<0.001$, all comparisons) in MetS rats vs $\mathrm{H}$, but adiponectin was lower in MetS at 9 months (MetS: $32 \pm 2, \mathrm{H}: 42 \pm 2, \mathrm{C}: 45 \pm 2$ $\mathrm{pg} / \mathrm{mL} ; \mathrm{p}<0.001$ ). GLUT4 protein was reduced in MetS as compared to $\mathrm{C}$ rats at 3, 6 and 9-mo, respectively (Heart: 54\%, 50\% and 57\%; Gastrocnemius: 37\%, 56\% and 50\%; Adipose tissue: 69\%, 61\% and 69\%).

Conclusions: MSG-treated SHR presented all metabolic syndrome characteristics, as well as reduced GLUT4 content, which must play a key role in the impaired glycemic homeostasis of the metabolic syndrome.

Keywords: Monosodium glutamate, Spontaneously hypertensive rats, Glucose transporter 4

\section{Background}

Metabolic syndrome is a highly prevalent condition [1] and a determinant of increased cardiovascular risk [2] and type 2 diabetes [3]. Insulin resistance is the key factor that leads to several of the abnormalities associated with the syndrome [4]. The link between insulin resistance and metabolic syndrome was suggested to be inflammation [5], which is the most widely accepted hypothesis for its development [5-9]. Besides, hypertension is related to

\footnotetext{
*Correspondence: beatrizschaan@gmail.com

'Laboratório de Experimentação Animal e Laboratório de Cardiologia

Molecular e Celular, Instituto de Cardiologia/Fundação, Universitária de Cardiologia, Av. Princesa Isabel, 395. Bairro Santana, Porto Alegre RS, 90620 001, Brazil

${ }^{3}$ Serviço de Endocrinologia, Hospital de Clínicas de Porto Alegre, Universidade Federal do Rio Grande do Sul, Porto Alegre, Brazil Full list of author information is available at the end of the article
}

insulin resistance [4], a feature that can be genetically induced $[10,11]$.

GLUT4 is the insulin-sensitive glucose transporter which main role is to provide the insulin-stimulated glucose uptake by adipose tissue, skeletal muscle and the heart, tissues that specifically express this protein [12]. It has been extensively reported that transgenic mice lacking or overexpressing GLUT4 respectively, decrease or increase whole-body insulin sensitivity [13], pointing out its role in the maintenance of glucose homeostasis. In obesity, the reduction of this transporter gene expression is directly related to the development of insulin resistance [14].

Inflammatory cytokines produced by the adipose tissue, such as TNF- $\alpha$ (tumor necrosis factor- $\alpha$ ) and interleukin-6 (IL-6) have been related to reduce GLUT4

\section{Ciomed Central}

(c) 2012 Leguisamo et al.; licensee BioMed Central Ltd. This is an Open Access article distributed under the terms of the Creative Commons Attribution License (http://creativecommons.org/licenses/by/2.0), which permits unrestricted use, distribution, and reproduction in any medium, provided the original work is properly cited. 
expression [8,9], consequently lowering glucose uptake by muscle, and participating on the compensatory hyperinsulinemia [7,15,16]. Administration of monosodium glutamate (MSG) to rats [17] or mice [18] is a wellknown animal model of obesity. Obesity development in adult rodents induced by neonatal injection of MSG was first proposed by Nemeroff and cols. [19]. This treatment induces neuroendocrine dysfunctions as a consequence of lesion in the arcuate nucleus of the hypothalamus, which compromises dopaminergic and cholinergic tubero-infudibular systems [20,21]. The neurotoxic effect of MSG is restricted to the neonatal period, because of the immature blood-brain barrier [22], and seems to be dose-dependent [23,24]. Hypophagia is usually observed $[24,25]$, and obesity derives from a lower metabolic rate [26], related to decreased thermogenesis [27], attributed to low sympathetic nervous system activity of brow adipose tissue [28]. Endocrine alterations such as decreased plasma growth hormone concentration [21] and increased plasma corticosterone concentration [23] can contribute to the development of obesity. Glucose homeostasis derangements seem to be more severe in mice than in rats; mice can develop diabetes $[29,30]$, and rats an insulin-resistant state without hyperglycemia [31]. Since the description of this animal model in the late seventies, it has been extensively used to investigate the pathophysiology of obesity and its potential therapeutic approaches.

On the other hand, MSG treatment of spontaneously hypertensive rats (SHR) could approach a classical animal model of the metabolic syndrome, by association of obesity with arterial hypertension, but there are reports that high blood pressure (BP) levels are attenuated in these animals [32]. Moreover, this animal model was not fully characterized as to the development and maintenance of the metabolic syndrome features over time. We hypothesized that the induction of obesity in hypertensive rats would determine a cluster of dysfunctions enough to characterize the metabolic syndrome, as it is observed in humans, pointing out reduced expression of GLUT4 in insulin-sensitive tissues as a marker of insulin resistance. Thus, the aim of this study was to characterize the metabolic syndrome in MSG-treated spontaneously hypertensive rats (SHR), focusing on GLUT4 protein expression and insulin resistance development, as well as on inflammatory cytokines and BP levels over time.

\section{Methods}

All animals were bred and kept under standard laboratory animal house conditions at the Animal Production and Research Unit of the Center for Scientific and Technological Development of Fundação Estadual de Produção e Pesquisa em Saúde do Rio Grande do Sul,
Brazil. The study was approved by the Research Ethics Committee of Instituto de Cardiologia do RS, protocol \#UP:4330. Animals received standard rat food and water ad libitum, and were maintained in controlled 12-h light/12-h dark cycle (6AM/6PM) and $20-25^{\circ} \mathrm{C}$ temperature conditions.

Neonate male SHR $(\mathrm{n}=18)$ were submitted to subcutaneous administration of monosodium glutamate $\left(\mathrm{MSG}\right.$, Sigma $\left.{ }^{\circledR}\right)$ diluted in saline solution $(0.9 \% \mathrm{NaCl})$, $5 \mathrm{mg} / \mathrm{g} /$ day, for 9 days (MetS), starting at day one of life. We also evaluated 18 SHR (group $\mathrm{H}$ ) and 18 WistarKyoto rats (group C) treated with saline solution subcutaneously for the same period. At 21 days of life, the animals were weaned and placed into plastic boxes, 4 animals per box.

General characteristics, insulin sensitivity (insulin tolerance test) and blood pressure (analyzed on a beatto-beat basis) were evaluated at 3, 6 and 9 months. The rats were euthanized with ketamine $(160 \mathrm{mg} / \mathrm{kg}$ body weight) and xylazine (10 mg/kg body weight). Tissues (heart, epididymal white adipose tissue and gastrocnemius muscle) were removed for GLUT4 analyses (Western blotting), and blood was collected for lipid profile, $\mathrm{C}$ reactive protein (CRP), interleukin 6 (IL-6), tumor necrosis factor- $\alpha$ (TNF- $\alpha)$ and adiponectin analysis at the end of each period of evaluation, 6 animals of each group/ period.

\section{General characteristics evaluation}

The animals were weighed and their naso-anal lengths were measured in dorsal decubitus on the day they were euthanized. The Lee Index was calculated according to the formula: (weight ${ }^{1 / 3} /$ naso anal length) [30].

\section{Insulin tolerance test}

The insulin tolerance test was performed as previously described [31] using human insulin (Humulin, Eli Lilly, São Paulo, Brasil). After $3 \mathrm{~h}$ of food restriction, animals were anesthetized with ketamine $(160 \mathrm{mg} / \mathrm{kg}$ body weight) and xylazine (10 $\mathrm{mg} / \mathrm{kg}$ body weight), and $0.75 \mathrm{U} / \mathrm{kg}$ body-weight of regular insulin was injected via the penile vein. Glycemia was measured by Accu-check strips system (Roche, Mannheim, Germany) before insulin injection and 4, 8, 12, 16 and 20 minutes after. The glucose decay constant rate (kITT) was calculated as described [31].

\section{Blood pressure recording}

The animals were anesthetized with ketamine $(160 \mathrm{mg} / \mathrm{kg}$ body weight) and xylazine (10 $\mathrm{mg} / \mathrm{kg}$ body weight) to place a polyethylene catheter (PE-10) inside the femoral artery. The cannula was filled with saline solution and positioned inside the abdominal aorta, through the left femoral artery, to record BP. The next day the arterial 
cannula was connected to a pressure transducer, linked by a channel selector to the CODAS analog-digital board in a microcomputer. The data obtained were recorded. For each pulse wave the same program calculated values for peak (systole), valley (diastole) and period (between one peak and the next), generating a spreadsheet with these values, which was analyzed in a Microsoft Excel 2007 software. Twenty-minute basal recordings were obtained to evaluate systolic and diastolic BP and heart rate, in the conscious animal.

\section{Tissues harvesting and euthanasia}

One day after the BP recording, the animals were anesthetized as described. Gastrocnemius muscle and epididymal white adipose tissue were removed, and then the animals were submitted to a thoracotomy and cardiac puncture to draw blood, and further heart harvesting, causing their death. Serum was separated by centrifugation and frozen at $-80^{\circ} \mathrm{C}$. Tissues were weighed and immediately frozen for further analysis.

\section{Western-blotting for GLUT4 protein}

The tissue samples were homogenized according to Machado et al. [29]. The gastrocnemius, heart and white adipose tissue were homogenized in buffer $(10 \mathrm{~m} M$ Tris$\mathrm{HCl}, 1 \mathrm{mM}$ EDTA and $250 \mathrm{~m} M$ saccarose, $\mathrm{pH}$ 7.4), using a Polytron homogenizer (Marconi, Piracicaba, Brazil) at 20,000 rpm for 30 seconds. Gastrocnemius and heart were homogenized in the same buffer (1:6 weight: volume), and centrifuged at $1,000 \mathrm{~g}$ for $10 \mathrm{~min}$. The supernatant was saved; the pellet was resuspended in $1 / 3$ of the initial volume, and centrifuged again at 1,000 g for $10 \mathrm{~min}$. The two supernatant solutions were mixed and submitted to centrifugation at 150,000 g for $75 \mathrm{~min}$. The final pellet was resuspended in $1 \mathrm{ml}$ of buffer as a total membrane fraction. The white adipose tissue was homogenized in the same buffer (1:4 weight:volume), and centrifuged at 2,000 g for 15 minutes. The fat globules were discarded, and the volume of the infranatant, a fat-free extract fraction, containing the microssomal and the plasma membrane proteins (corresponding to total membrane fraction), was saved for further analysis. All procedures were carried out at $4{ }^{\circ} \mathrm{C}$.

GLUT4 expression was determined by Western Blot. Briefly, The total protein concentration of the samples was determined by the Bradford method [33]. Equal quantities of total proteins $(50 \mu \mathrm{g})$ were solubilized in Laemmli buffer, electrophorezed in sodium dodecyl sulfate/polyacrylamide gel electrophoresis (SDS-PAGE $10 \%$ ), and transferred to the nitrocellulose membrane (GE Healthcare, Amersham Biosciences, UK). After transfer, the membranes were blocked with non fat dried milk, and subjected to immunodetection using antiGLUT4 antibody (Chemicon, Billerica, CA, USA) at a dilution of $1: 3,000,37^{\circ} \mathrm{C}$ for 3 hours. The immunoblots were revealed and visualized by enhanced chemiluminescence using ECL kit (GE Healthcare), and analyzed by optical densitometry using Image Quant TL software (GE Healthcare, New York, USA). For white adipose tissue analysis, the membranes were reprobed with anti$\beta$-actin antibody (Monoclonal anti- $\beta$-actin antibody AC-74, A2228, Sigma-Aldrich), and GLUT4 values were normalized by the respective $\beta$-actin value. For heart and gastrocnemius analysis, densitometric analysis of total protein in the lanes was performed, between 35 and $130 \mathrm{kDa}$ of range (based on Page Ruler Prestained Protein Ladder $^{\circledR}$, Thermo Scientific, USA), in Ponceau stained membranes. These values were used to normalize the respective GLUT4 values [34]. The final results were expressed as arbitrary units (AU).

\section{Lipid profile and inflammatory markers}

Total cholesterol, HDL-cholesterol and triglycerides concentrations were analyzed using commercial kits (Labtest $^{\circledR}$, Lagoa Santa, MG, Brazil).

Immunodetection of inflammatory markers and adiponectin were analyzed by the immunoenzymatic method (ELISA) according to the respective manufacturer's instructions: CRP (USA; Ebiosciences ${ }^{\circledR}$, San Diego, CA USA), TNF- $\alpha$ (Cellsciences ${ }^{\circledR}$, Canton, MA, USA), IL-6 (Cellsciences $^{\circledR}$, Canton, MA, USA) and adiponectin (Chemicon ${ }^{\circledR}$, Billerica, MA). The reading was obtained by spectrophotometry (Spectramax ${ }^{\circledR}$, Molecular Devices Corporation, Sunnyvale, CA, USA) at 450nm and compared to a standard curve obtained with known concentrations of recombinant mediators. The minimum values of detection, intra-assay variability coefficients and interassay variability coefficients according to the manufacturer were, respectively: CRP: $2.5 \mathrm{pg} / \mathrm{mL},<8 \%$ and $<7 \%$; TNF- $\alpha$ : $25 \mathrm{pg} / \mathrm{mL},<10 \%$ and $<12 \%$; IL-6: $2 \mathrm{pg} / \mathrm{mL} ;<10 \%$ and $<12 \%$; adiponectin: $15.6 \mathrm{pg} / \mathrm{mL},<10 \%$ and $<10 \%$.

\section{Statistical analysis}

The results are presented as mean \pm standard deviation and compared by two-way analysis of variance (ANOVA), followed by the Bonferroni's post-hoc test. The level of significance was $5 \%$ for all tests performed. All analyses were performed using the SPSS for Windows, version 17.0.

\section{Results}

General characteristics of the animals are shown in Table 1. Animals in the MetS group weighed less than $\mathrm{C}$ and $\mathrm{H} \quad(\mathrm{p}<0.001$ for both comparisons $)$ at 6 and 9 months of age. The heart and gastrocnemius mass were reduced in the MetS animals $(\mathrm{p}<0.001$ for both comparisons). However, the weight of epididymal white fat was greater in the MetS group vs. $\mathrm{C}$ and $\mathrm{H}(\mathrm{p}<0.001$ for both 
Table 1 General characteristics of the animals studied at 3, 6 and 9 months of age

\begin{tabular}{|c|c|c|c|c|c|c|c|c|c|}
\hline & \multicolumn{3}{|c|}{3 months } & \multicolumn{3}{|c|}{6 months } & \multicolumn{3}{|c|}{9 months } \\
\hline & $\mathrm{C}$ & $\mathbf{H}$ & MetS & $\mathrm{C}$ & $\mathbf{H}$ & MetS & $\mathrm{C}$ & $\mathbf{H}$ & MetS \\
\hline Body weight (g) & $262 \pm 29$ & $278 \pm 9$ & $254 \pm 18$ & $349 \pm 13$ & $377 \pm 11$ & $291 \pm 26^{a}$ & $355 \pm 16$ & $363 \pm 11$ & $305 \pm 6^{a}$ \\
\hline Lee index & $0.22 \pm 0.1$ & $0.26 \pm 0.1$ & $0.33 \pm 0.1^{\mathrm{a}}$ & $0.23 \pm 0.1$ & $0.27 \pm 0.1$ & $0.33 \pm 0.1^{a}$ & $0.26 \pm 0.1$ & $0.29 \pm 0.1$ & $0.32 \pm 0,1^{a}$ \\
\hline Heart weight (g) & $0.91 \pm 0.21$ & $0.95 \pm 0.11$ & $0.80 \pm 0.10^{a}$ & $1.12 \pm 0.25$ & $1.22 \pm 0.18$ & $0.90 \pm 0.13^{a}$ & $1.22 \pm 0.21$ & $1.26 \pm 0.19$ & $0.80 \pm 0.12^{a}$ \\
\hline Gastrocnemius weight (g) & $1.39 \pm 0.23$ & $1.41 \pm 0.30$ & $1.10 \pm 0.21$ & $1.47 \pm 0.21$ & $1.59 \pm 0.19$ & $1.28 \pm 0.14$ & $1.61 \pm 0.22$ & $1.70 \pm 0.26$ & $1.31 \pm 0.18^{a}$ \\
\hline WAT weight (g) & $0.80 \pm 0.16$ & $0.88 \pm 0.18$ & $1.20 \pm 0.17^{\mathrm{a}}$ & $1.09 \pm 0.18$ & $1.19 \pm 0.21$ & $1.42 \pm 0.22^{\mathrm{a}}$ & $1.26 \pm 0.21$ & $1.29 \pm 0.31$ & $1.66 \pm 0.36^{\mathrm{a}}$ \\
\hline Total cholesterol (mg/dl) & $57 \pm 12$ & $56 \pm 7$ & $56 \pm 7$ & $70 \pm 21$ & $78 \pm 21$ & $76 \pm 13$ & $83 \pm 7$ & $77 \pm 21$ & $76 \pm 13$ \\
\hline $\mathrm{HDL}-\mathrm{c}(\mathrm{mg} / \mathrm{dl})$ & $54 \pm 4$ & $54 \pm 2$ & $54 \pm 2$ & $55 \pm 7$ & $51 \pm 3$ & $37 \pm 6^{a}$ & $53 \pm 9$ & $50 \pm 7$ & $39 \pm 5^{a}$ \\
\hline Triglycerides (mg/dl) & $49 \pm 13$ & $49 \pm 15$ & $49 \pm 15$ & $56 \pm 6$ & $58 \pm 18$ & $104 \pm 19^{a}$ & $66 \pm 11$ & $170 \pm 41^{a}$ & $444 \pm 64^{a}$ \\
\hline
\end{tabular}

$C$ : Wistar-Kyoto rats that did not receive any treatment; $\mathrm{H}$ : spontaneously hypertensive rats that did not receive any treatment; MetS: spontaneously hypertensive rats that received MSG during the neonatal period. WAT: white adipose tissue; HDL-c: high density lipoprotein cholesterol. The table shows only differences among groups at the same time of evaluation, not inside groups throughout time. Differences among groups over time are described in the results section. ${ }^{a}$ $\mathrm{p}<0.05$ vs. C. Two-way ANOVA followed by Bonferroni's post hoc test.

comparisons) at all ages studied, and consequently, the Lee index was also higher in all ages $(\mathrm{p}<0.001)$, revealing the obesity of MetS rats. MetS rats had progressively increased triglycerides with aging (6 mo: $\mathrm{p}<0.001 \mathrm{MetS}$ vs. $\mathrm{C}$ and $\mathrm{p}=0.002 \mathrm{MetS}$ vs. $\mathrm{H} ; 9$ mo: $\mathrm{p}<0.001$ for MetS vs. $\mathrm{C}$ and $\mathrm{H}$ ), as well as reduced HDL-cholesterol (6 mo: $\mathrm{p}<0.001$ MetS vs. $\mathrm{C}$ and $\mathrm{p}=0.014$ MetS vs. $\mathrm{H} ; 9$ mo: $\mathrm{p}=0.004$ MetS vs. $\mathrm{C}$ and $\mathrm{p}=0.009$ MetS vs. $\mathrm{H}$ ), with a more marked difference among groups at 9 months of age. Interestingly, $\mathrm{H}$ animals with 9 months of age also had increased triglyceride levels when compared with $\mathrm{C}$ $(p<0.001)$. Total cholesterol of all groups was higher at 6 and 9 months when compared to 3 months of age, however, there were no differences among groups within each age.
Mean BP was similarly higher in $\mathrm{H}$ and MetS groups at all ages, as compared to the $\mathrm{C}$ group (Figure 1). There were no changes in BP over time in the groups studied.

Figure 2 shows the results of the insulin tolerance test (Panel A) and glycemia (Panel B) after 8 hours of food deprivation. Animals from the MetS group were insulinresistant at all ages, as compared to respective $\mathrm{C}$ and $\mathrm{H}$ groups although insulin resistance did not increase over time. Furthermore, $\mathrm{H}$ animals become insulin-resistant at 6 and 9 months of age, as compared to C (no difference between $\mathrm{C}$ and $\mathrm{H}$ was observed at 3 months of age). Glycemia was higher in $\mathrm{H}$ and MetS groups at all ages as compared to the $\mathrm{C}$ group (Figure 2, Panel B).

Figure 3 shows the results of the cytokines (TNF-alpha and IL-6), as well as CRP and adiponectin. IL-6 (Panel

\section{Blood Pressure}

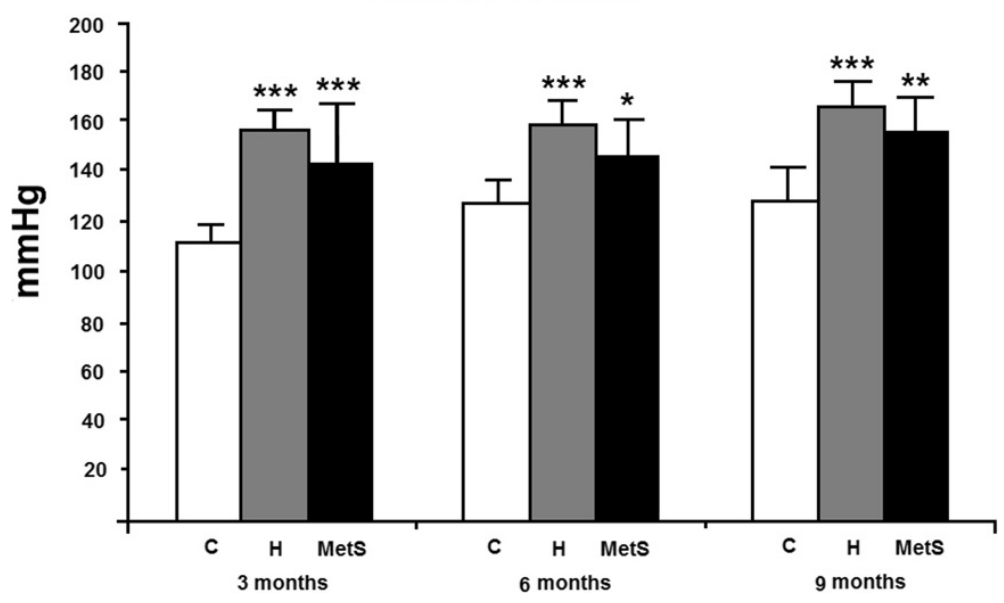

Figure 1 Mean blood pressure of the animals studied, at 3, 6 and 9 months of age. C: Wistar-Kyoto rats that did not receive any treatment; $\mathrm{H}$ : spontaneously hypertensive rats that did not receive any treatment; MetS: spontaneously hypertensive rats that received MSG during the neonatal period. $n=6$ in all groups. Two-way analysis of variance (ANOVA): group $(p<0.001)$, time $(p=0.431)$ and interaction $(p=0.016)$, followed by the Bonferroni's post hoc test: ${ }^{*} p<0.05,{ }^{* *} p<0.01$ and ${ }^{* * *} p<0.001$ vs. C at the same time. 


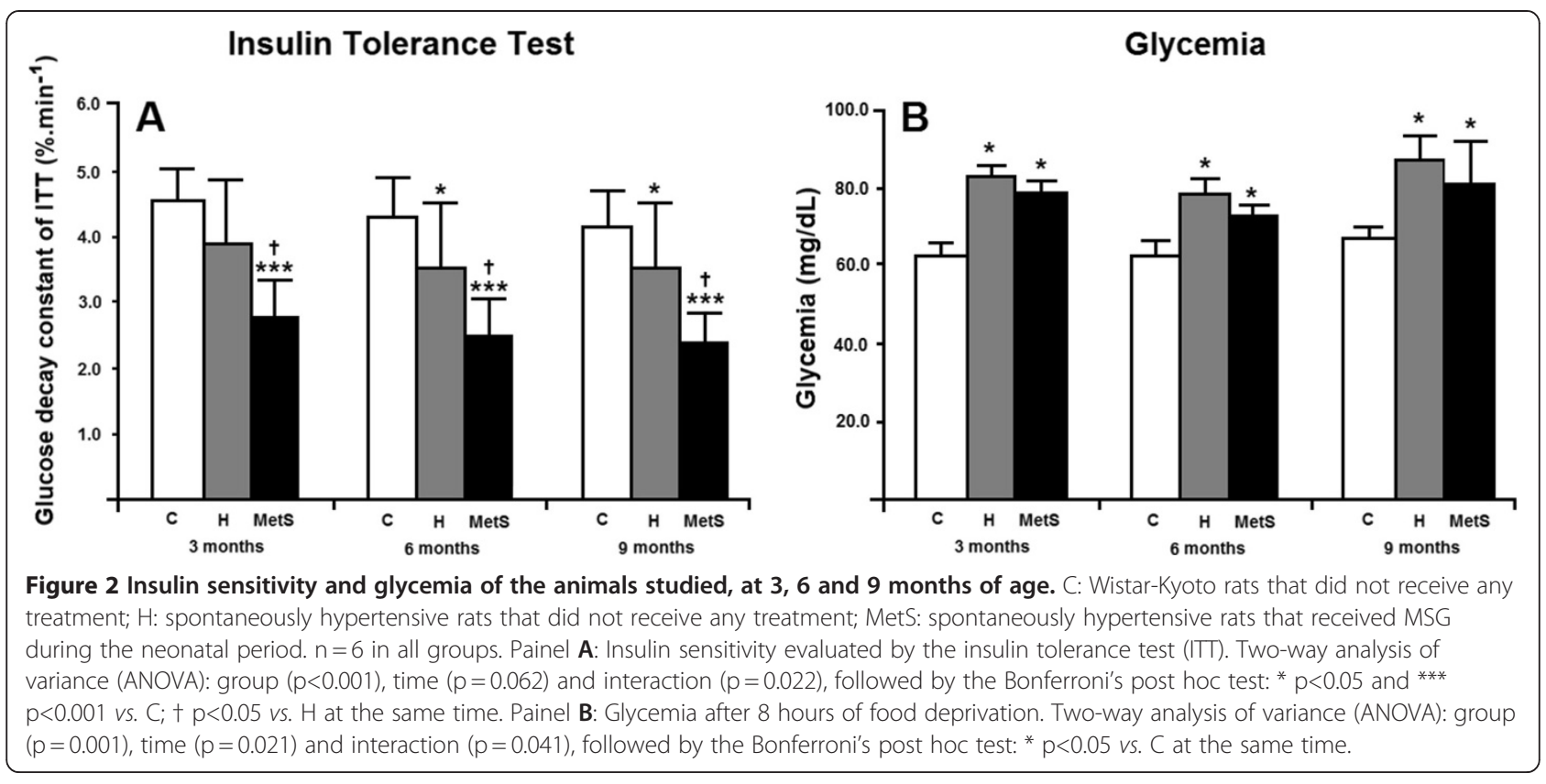

A) was elevated in MetS animals at 6 and 9 months of age, as compared to both $\mathrm{C}$ and $\mathrm{H}$ animals. A curious result was observed at 3 month of age, when IL-6 was lower in MetS and $\mathrm{H}$ animals, as compared do C. CRP (Panel B) and TNF-alpha (Panel C) were also higher in MetS animals in all ages, as compared do $\mathrm{C}$ and $\mathrm{H}$ animals; indeed, these cytokines were elevated in $\mathrm{H}$, as compared to $\mathrm{C}$ at all ages, except at 9 months for TNFalpha. Finally, adiponectin (Panel D) was altered only at 9 months of age, when it was reduced in MetS animals, as compared to both $\mathrm{C}$ and $\mathrm{H}$ animals.

GLUT4 expression (Figure 4) was lower in heart (panel A), gastrocnemius (Panel B) and white adipose tissue (Panel $\mathrm{C}$ ) at all ages in the MetS group, as compared to $\mathrm{C}$ and $\mathrm{H}$. The reduction of GLUT4 in the heart of MetS rats was $54 \%, 50 \%$ and $57 \%$ at 3, 6 and 9 months of age, respectively, as compared to $\mathrm{C}$ group. In the gastrocnemius of Mets animals, GLUT4 was lower $37 \%, 56 \%$ and $50 \%$ as compared to C group at 3, 6 and 9 months, respectively. Finally, the GLUT4 in the adipose tissue MetS group showed a reduction of $69 \%, 61 \%$ and $69 \%$ at 3, 6 and 9 months of age, respectively.

\section{Discussion}

This study showed a reduction of GLUT4 protein content of insulin-sensitive tissues in an animal model of metabolic syndrome, a fundamental mechanism to impair glucose uptake and glucose homeostasis. This regulation, not yet seen, began at 3 months of age, and was not reverted as time passed. Furthermore, this glucose transporter modulation was accompanied by inflammation, insulin resistance and hypertension, also here described in the same animal model.
The use of MSG in genetically hypertensive rats led these animals to progressively increase body adiposity and hypertriglyceridemia; besides, developing and maintaining insulin resistance, low HDL-cholesterol, high blood pressure levels, and inflammation throughout the period studied. Other animal models used showed that high-fat-fed SHRs did not show changes in plasma concentrations of total cholesterol and triglycerides, although plasma concentrations of free fatty acids were higher as compared to normal diet-fed SHRs [35]. Mice fed on high-carbohydrate and high-fat diet (cafeteria diet) had increased body weight, abdominal fat deposition, hyperinsulinaemia, hyperglycaemia and hyperleptinaemia, but no hypertension [36,37]. Although these are examples of models of metabolic syndrome [38], our study clearly shows the possibility of reproducing the whole metabolic syndrome in laboratory animals in a low-cost and easily-obtained model.

The increased Lee index and epididymal fat mass observed in MetS animals confirmed their obese condition, as it has been described in MSG-treated normotensive rats and mice [32,39]. MSG-treated animals, compared to their controls, may have a lower absolute weight, as we also found in MetS, which has been proposed to be a result of decreasing growth hormone (GH) secretion [40]. Accordingly, lean mass may be decreased in MSG animals [41], a feature that we also observed in SHR treated with MSG, which presented lower heart and skeletal muscle mass. In addition to low GH levels, high corticosterone levels [42] were also described in MSG animals, and both hormonal modulations contribute to decrease synthesis and increase catabolism of proteins, thus diminishing muscle mass [43]. Furthermore, 


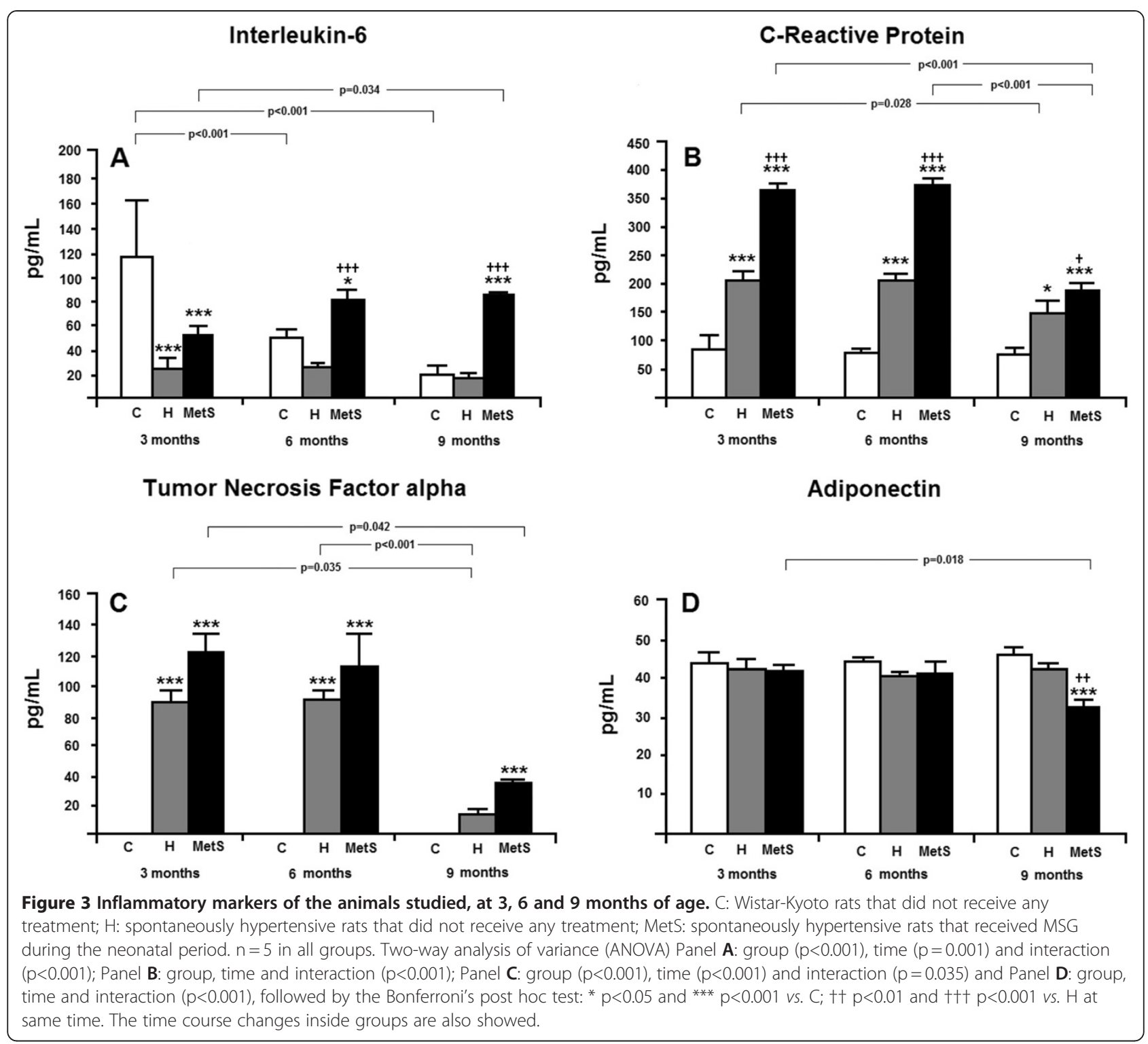

together with decreasing sympathetic activity [28] this hormonal imbalance contributes to conserve energy, accumulating fat. It is important to highlight that MSG should be administered in the neonatal period to determine all the derangements related to obesity described, as use in later periods of life [44] would not result in the characteristic hypothalamic lesions [20,21], because of the protective effects of the blood-brain barrier [22].

In metabolic syndrome, however, beyond obesity, hypertension is a key feature, which is not present when MSG is used in mice [30] and Wistar rats [45], but was effectively shown in the present study treating SHR. Other authors described attenuation of high BP levels in MSG-treated SHR [32,39], a finding that we did not observe, probably because the cardiovascular evaluation method we used is more appropriate (direct BP measurement). The studies mentioned found controversial results, possibly due to the fact that all measured mean BP using tail plethysmography. Furthermore, variable protocols of neonatal MSG treatment have been used, probably altering severity and/or time of induction of the alterations. It is well-known that, in SHR, BP rises progressively over lifetime, while in our study, the MSGtreated SHR had higher BP than the normotensive rats at all ages studied, but remained stable, not increasing over time. This fact might be related to low sympathetic activity described in MSG-treated animals [28].

Fulfilling the picture of metabolic syndrome, MSGtreated SHR presented obesity and high BP levels associated with insulin resistance, hypertriglyceridemia and reduced HDL cholesterol levels with normal total cholesterol levels. Spontaneously hypertensive rats are 

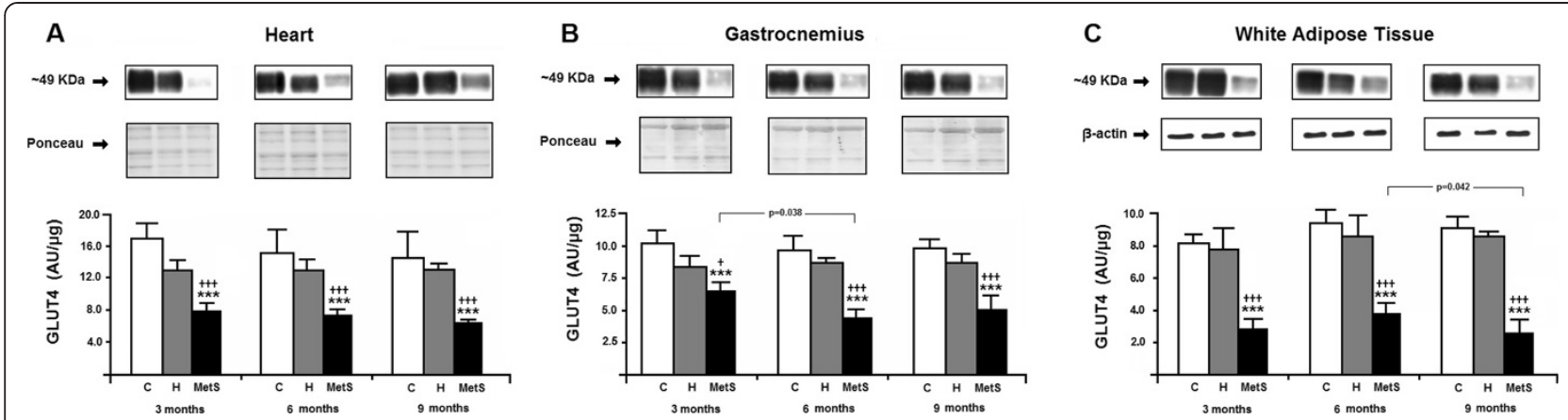

Figure 4 Total GLUT4 protein in heart (A), gastrocnemius muscle (B) and epididymal white adipose tissue (C) from the animals studied. $\mathrm{C}$ : Wistar-Kyoto rats that did not receive any treatment; $\mathrm{H}$ : spontaneously hypertensive rats that did not receive any treatment; MetS: spontaneously hypertensive rats that received MSG during the neonatal period. On the top, representative images of GLUT4 and respective loading controls. Loading controls are $\beta$-actin for white adipose tissue, and total proteins of 35 to $130 \mathrm{kDa}$ range of the Ponceau stained membrane for heart and gastrocnemius, as described in Methods. On the bottom, the graphs show means \pm SEM of $n=5$ animals. Two-way analysis of variance (ANOVA) Panel A: group, time and interaction ( $p<0.001)$; Panel $\mathbf{B}$ : group $(p=0.006)$, time $(p<0.001)$ and interaction $(p=0.003)$; Panel C: group, time and interaction $(p<0.001)$, followed by the Bonferroni's post hoc test: ${ }^{* *} p<0.001$ vs. $C_{\text {; }}+p<0.05$ and $+1+p<0.001$ vs. H at same time. The time course changes inside groups are also showed.

typically insulin resistant [12], which we also observed in the MSG-treated SHR. However, SHR are not obese, and their visceral fat content is similar to that of normotensive Wistar rats [46], which was strongly changed by using MSG. Insulin resistance in SHR is partially ascribed to the characteristic sympathetic hyperactivity they present, which promotes reduced activity of the insulin signaling cascade and, consequently, can reduce GLUT4 translocation and/or expression [47]. Furthermore, norepinephrine inhibits insulin-mediated glucose uptake in muscle [48] and blocks insulin inhibitory action on liver glucose production [49], all these effects contributing to impair glycemic homeostasis. The characteristic lipid profile of insulin-resistant states was observed from 6 months of age and beyond for the MSG-treated SHR, as observed for non-MSG treated SHR [50], but not for Wistar-Kyoto rats. Based on these facts, we can understand that increased sympathetic activity may induce or worsen installed insulin resistance, closing the circle which perpetuates the existence of both insulin resistance and high BP levels.

Beyond its classic metabolic actions, insulin is also antiinflammatory, decreasing activity of pro-inflammatory cytokines, such as TNF- $\alpha$ and IL-6, as well as repressing the transcription factor nuclear factor кB (NFкB) [51]. In MSG-treated mice, Furuya and collaborators [52] demonstrated that hypertrophyc adipocytes triggered local inflammatory activity with increased macrophage infiltration and TNF- $\alpha$ and IL-6 expression, depicting high plasma concentration of the cytokines. This was accompanied by decreased GLUT4 content in white adipose tissue and reversed by atorvastatin treatment [52]. We showed that inflammation is exacerbated in MSG-treated SHR from 3 months of age on, along with GLUT4 reduction in all insulin-sensitive tissues. TNF- $\alpha$ rise, especially, can reduce the expression of IRS-1 and GLUT4, as well as of the hormone-sensitive lipase, adiponectin and PPAR $\gamma$ [53]. All these processes are known to contribute to lipolysis and insulin resistance, and were also observed in these animals since the age of 3 months. Adiponectin reduction in MSG-treated SHR at the age of 9 months is probably due to the exacerbation of hypertriglyceridemia at this age, which acts as an independent causal factor for hypoadiponectinemia [54]. Besides, hypoadiponectinemia probably occurs only at the age of 9 months because of its known relationship with the severity of obesity [55].

Insulin resistance of MSG-treated SHR is in accordance with the reduction of GLUT4 content in all insulin-sensitive tissues analyzed, corroborating previous data in MSG-treated mice in all cell fractions of adipose tissue with no change in the relative GLUT4 translocation to the plasma membrane [30] and also in the same tissue in humans [56]. Moreover, low GLUT4 protein content in skeletal muscle and heart was also shown in MSG-treated mice [18]. In MSG-treated SHR, GLUT4 on insulin-sensitive tissues had not been reported yet, especially its time-course changes through aging, as here reported.

Skeletal and heart GLUT4 protein were reduced from the age of 3 months and did not worsen over time, following the stable profile of insulin resistance in MSG-treated SHR. It is known that in the SHR, plasma membrane myocyte GLUT4 increases with age (12 weeks), but at 20 weeks, GLUT4 contents tends to reach the initial levels (8 weeks) [57]. Moreover, reduced insulin-induced GLUT4 translocation [47] and/or total content was also showed before [57]. Pharmacological treatment of arterial hypertension with captopril can virtually re-establish the glucose transporter contents 
[57]. On the other hand, investigations have shown that GLUT4 translocation in skeletal muscle and heart is stimulated by bradykinin [58], which enhances insulininduced phosphorylation of insulin receptors and insulinstimulated association of IRS-1 and phosphatidylinositol3-kinase in skeletal muscle of aged rats [59], all of which are essential for insulin-mediated GLUT4 translocation and glucose transport. Both cases demonstrate that the amount of GLUT4 is related to blood pressure levels. Anyhow, it is known that the behavior of this transporter in the skeletal muscle does not always reflect what happens in the white adipose tissue [60], and, indeed, in this tissue, we find a progressive reduction of its content in MSG-treated SHR, especially at the age of 9 months.

In the heart, in turn, it is known that insulin resistance together with the excess of free fatty acids - as we find in MSG-treated SHR - are responsible for contractility dysfunction $[61,62]$. Since the muscle contraction also induces GLUT4 translocation to the plasma membrane, contractility dysfunction is directly related to reduced plasma membrane GLUT4 content [63]. Furthermore, the excess of free fatty acids alone can interfere in glucose transport, since it reduces GLUT4 expression in the heart, but not that of the free fatty acid transporter [64]. In rats with insulin resistance induced by a fructose-rich diet, cardiomyocytes present low glucose input in response to ischemia, a consequence of GLUT4 translocation reduction [65]. We found a reduction of GLUT4 content in heart of MSG-treated SHR at the age of 3, 6 and 9 months, which can be explained by the hypothesis that the reduction of this transporter in the heart occurs when obesity and insulin resistance are established [41]. The normotensive and hypertensive control groups did not present differences in the GLUT4 content in the heart, at the age of 6 months [12]. In the MSG-treated SHR, time-course of changes of insulinsensitive GLUT4 protein content had not yet been described in the literature.

\section{Conclusions}

The present study depicts in obese hypertensive rats a reduction in GLUT4 expression, accompanied by whole-body insulin resistance, and increased plasma concentration of inflammatory markers. These findings characterize an animal model of metabolic syndrome, as it has been observed in humans. In general, the alterations have persisted unaltered during the aging process, from 3 to 9 months of age. Thus, the MSGtreated SHR can be used as an experimental model to investigate pharmacological approaches for the metabolic syndrome, as well as its interaction with other diseases.

\section{Competing interests}

The authors declare that they have no competing interests.

\section{Authors' contributions}

NMM was involved in conception and design of the study, data collection, data analysis and interpretation, as well as drafting and editing the final document for publication. AML was involved in data analysis and interpretation, as well as drafting and editing the final document for publication. UFM was involved in conception and design of the study, data analysis and interpretation, as well as reviewing all parts of the final document for publication. GHP was involved in data collection, data analysis and interpretation. OMM and MMM were involved in data collection (molecular analysis), data analysis and interpretation. BDS was involved in conception and design of the study, data analysis and interpretation, as well as writing, drafting and editing the final document for publication. All authors read and approved the final manuscript.

\section{Acknowledgements}

This work was supported by grants from Rio Grande do Sul and Sao Paulo State Foundation for Research (Fapergs and Fapesp, respectively), CNPq, Capes (Procad 113/2007) and Department of Biochemistry at UFRGS.

\section{Author details}

${ }^{1}$ Laboratório de Experimentação Animal e Laboratório de Cardiologia Molecular e Celular, Instituto de Cardiologia/Fundação, Universitária de Cardiologia, Av. Princesa Isabel, 395. Bairro Santana, Porto Alegre RS, 90620 001, Brazil. ²Departamento de Fisiologia e Biofísica do Instituto de Ciências Biomédicas, Universidade de São Paulo, São Paulo, Brazil. ${ }^{3}$ Serviço de Endocrinologia, Hospital de Clínicas de Porto Alegre, Universidade Federal do Rio Grande do Sul, Porto Alegre, Brazil.

Received: 11 April 2012 Accepted: 11 July 2012

Published: 16 August 2012

\section{References}

1. Ford ES, Li C, Zhao G: Prevalence and correlates of metabolic syndrome based on a harmonious definition among adults in the US. J Diabetes 2010, 2:180-193.

2. Wildman RP, McGinn AP, Lin J, Wang D, Muntner P, Cohen HW, Reynolds K, Fonseca V, Sowers MR: Cardiovascular disease risk of abdominal obesity vs. metabolic abnormalities. Obesity (Silver Spring) 2011, 19:853-860.

3. Aschner P: Metabolic syndrome as a risk factor for diabetes. Expert Rev Cardiovasc Ther 2010, 8:407-412.

4. Reaven GM: Banting lecture 1988. Role of insulin resistance in human disease. Diabetes 1988, 37:1595-1607.

5. Choi KM, Ryu OH, Lee KW, Kim HY, Seo JA, Kim SG, Kim NH, Choi DS, Baik $\mathrm{SH}$ : Serum adiponectin, interleukin-10 levels and inflammatory markers in the metabolic syndrome. Diabetes Res Clin Pract 2007, 75:235-240.

6. Emanuela F, Grazia M, de Marco R, Maria Paola L, Giorgio F, Marco B: Inflammation as a link between obesity and metabolic syndrome. J Nutr Metab 2012, 2012:476380.

7. Hotamisligil GS, Arner P, Caro JF, Atkinson RL, Spiegelman BM: Increased adipose tissue expression of tumor necrosis factor-alpha in human obesity and insulin resistance. J Clin Invest 1995, 95:2409-2415.

8. Rotter V, Nagaev I, Smith U: Interleukin-6 (IL-6) induces insulin resistance in 3T3-L1 adipocytes and is, like IL-8 and tumor necrosis factor-alpha, overexpressed in human fat cells from insulin-resistant subjects. J Biol Chem 2003, 278:45777-45784.

9. Stephens JM, Lee J, Pilch PF: Tumor necrosis factor-alpha-induced insulin resistance in 3T3-L1 adipocytes is accompanied by a loss of insulin receptor substrate-1 and GLUT4 expression without a loss of insulin receptor-mediated signal transduction. J Biol Chem 1997, 272:971-976.

10. Shehata MF: Important genetic checkpoints for insulin resistance in saltsensitive (S) Dahl rats. Cardiovasc Diabetol 2008, 7:19.

11. Pfeffer J, Pfeffer $M$, Fishbein M, Frohlich E: Cardiac function and morphology with aging in the spontaneously hypertensive rat. Am J Physiol 1979, 237:H461-H468.

12. Lehnen AM, Leguisamo NM, Pinto GH, Markoski MM, De Angelis K, Machado UF, Schaan B: The beneficial effects of exercise in rodents are preserved after detraining: a phenomenon unrelated to GLUT4 expression. Cardiovasc Diabetol 2010, 9:67.

13. Carvalho E, Kotani K, Peroni OD, Kahn BB: Adipose-specific overexpression of GLUT4 reverses insulin resistance and diabetes in mice lacking GLUT4 selectively in muscle. Am J Physiol Endocrinol Metab 2005, 289:E551-E561. 
14. Garvey W, Malanu L, Zhu J, Brechtel-Hook G, Wallace P, Baron A: Evidence of the defects in trafficking and translocation of GLUT4 glucose transporter in skeletal muscle as a cause of human insulin resistance. J Clin Invest 1998, 101:2377-2386.

15. Razny U, Kiec-Wilk B, Wator L, Polus A, Dyduch G, Solnica B, Malecki M, Tomaszewska R, Cooke JP, Dembinska-Kiec A: Increased nitric oxide availability attenuates high fat diet metabolic alterations and gene expression associated with insulin resistance. Cardiovasc Diabetol 2011, $10: 68$

16. Gray S, Feinberg MW, Hull S, Kuo CT, Watanabe M, Sen-Banerjee S, DePina A, Haspel R, Jain MK: The Kruppel-like factor KLF15 regulates the insulinsensitive glucose transporter GLUT4. J Biol Chem 2002, 277:34322-34328.

17. Hirata AE, Andrade IS, Vaskevicius P, Dolnikoff MS: Monosodium glutamate (MSG)-obese rats develop glucose intolerance and insulin resistance to peripheral glucose uptake. Braz J Med Biol Res 1997, 30:671-674.

18. Papa PC, Seraphim PM, Machado UF: Loss of weight restores GLUT 4 content in insulin-sensitive tissues of monosodium glutamate-treated obese mice. Int J Obes Relat Metab Disord 1997, 21:1065-1070.

19. Nemeroff CB, Konkol RJ, Bissette G, Youngblood W, Martin JB, Brazeau P, Rone MS, Prange AJ Jr, Breese GR, Kizer JS: Analysis of the disruption in hypothalamic-pituitary regulation in rats treated neonatally with monosodium L-glutamate (MSG): evidence for the involvement of tuberoinfundibular cholinergic and dopaminergic systems in neuroendocrine regulation. Endocrinology 1977, 101:613-622.

20. Nemeroff CB, Grant LD, Bissette G, Ervin GN, Harrell LE, Prange AJ Jr: Growth, endocrinological and behavioral deficits after monosodium Lglutamate in the neonatal rat: possible involvement of arcuate dopamine neuron damage. Psychoneuroendocrinology 1977, 2:179-196.

21. Nemeroff CB, Lipton MA, Kizer JS: Models of neuroendocrine regulation: use of monosodium glutamate as an investigational tool. Dev Neurosci 1978, 1:102-109.

22. Kizer JS, Nemeroff CB, Youngblood WW: Neurotoxic amino acids and structurally related analogs. Pharmacol Rev 1977, 29:301-318.

23. Lorden JF, Caudle A: Behavioral and endocrinological effects of single injections of monosodium glutamate in the mouse. Neurobehav Toxicol Teratol 1986, 8:509-519.

24. Olney JW: Brain lesions, obesity, and other disturbances in mice treated with monosodium glutamate. Science 1969, 164:719-721.

25. Caputo FA, Scallet AC: Postnatal MSG treatment attenuates angiotensin II (All) induced drinking in rats. Physiol Behav 1995, 58:25-29.

26. Djazayery A, Miller DS, Stock MJ: Energy balances in obese mice. Nutr Metab 1979, 23:357-367.

27. Duloo AG, Miller DS: Unimpaired thermogenic response to noradrenaline in genetic (ob/ob) and hypothalamic (MSG) obese mice. Biosci Rep 1984 4:343-349.

28. Yoshida T, Nishioka H, Nakamura Y, Kanatsuna T, Kondo M: Reduced norepinephrine turnover in brown adipose tissue of pre-obese mice treated with monosodium-L-glutamate. Life Sci 1985, 36:931-938.

29. Machado U, Shimizu I, Saito M: Reduced content and preserved translocation of glucose transporter (GLUT 4) in white adipose tissue of obese mice. Physiol Behav 1994, 55:621-625.

30. Machado U, Shimizu Y, Saito M: Decreased glucose transporter (GLUT 4) content in insulin-sensitive tissues of obese aurothioglucose- and monosodium glutamatetreated mice. Horm Metab Res 1993, 25:462-465.

31. Mori RC, Hirabara SM, Hirata AE, Okamoto MM, Machado UF: Glimepiride as insulin sensitizer: increased liver and muscle responses to insulin. Diabetes Obes Metab 2008, 10:596-600.

32. van den Buuse M, Versteeg DH, de Jong W: Effects of neonatal treatment with monosodium-glutamate in spontaneously hypertensive rats. Brain Res 1985, 351:135-138

33. Bradford MM: A rapid and sensitive method for the quantitation of microgram quantities of protein utilizing the principle of protein-dye binding. Anal Biochem 1976, 72:248-254.

34. Ferguson RE, Carroll HP, Harris A, Maher ER, Selby PJ, Banks RE: Housekeeping proteins: a preliminary study illustrating some limitations as useful references in protein expression studies. Proteomics 2005, 5:566-571.

35. Chung S, Park CW, Shin SJ, Lim JH, Chung HW, Youn DY, Kim HW, Kim BS, Lee JH, Kim GH, Chang YS: Tempol or candesartan prevents high-fat dietinduced hypertension and renal damage in spontaneously hypertensive rats. Nephrol Dial Transplant 2010, 25:389-399.
36. Murase $T$, Mizuno T, Omachi T, Onizawa K, Komine $Y$, Kondo H, Hase T, Tokimitsu I: Dietary diacylglycerol suppresses high fat and high sucrose diet-induced body fat accumulation in C57BL/6J mice. J Lipid Res 2001, 42:372-378.

37. Parekh PI, Petro AE, Tiller JM, Feinglos MN, Surwit RS: Reversal of dietinduced obesity and diabetes in C57BL/6J mice. Metabolism 1998, 47:1089-1096

38. Sampey BP, Vanhoose AM, Winfield HM, Freemerman AJ, Muehlbauer MJ, Fueger PT, Newgard CB, Makowski L: Cafeteria diet is a robust model of human metabolic syndrome with liver and adipose inflammation: comparison to high-fat diet. Obesity (Silver Spring) 2011, 19:1109-1117.

39. Iwase M, Yamamoto M, lino K, Ichikawa K, Shinohara N, Yoshinari M, Fujishima M: Obesity induced by neonatal monosodium glutamate treatment in spontaneously hypertensive rats: an animal model of multiple risk factors. Hypertens Res 1998, 21:1-6.

40. Gong SL, Xia FQ, Wei J, Li XY, Sun TH, Lu Z, Liu SZ: Harmful effects of MSG on function of hypothalamus-pituitary-target gland system. Biomed Environ Sci 1995, 8:310-317.

41. de Carvalho Papa P, Vargas AM, da Silva JL, Nunes MT, Machado UF: GLUT4 protein is differently modulated during development of obesity in monosodium glutamate-treated mice. Life Sci 2002, 71:1917-1928.

42. Dolnikoff MS, Kater CE, Egami M, de Andrade IS, Marmo MR: Neonatal treatment with monosodium glutamate increases plasma corticosterone in the rat. Neuroendocrinology 1988, 48:645-649.

43. Haber RS, Weinstein SP: Role of glucose transporters in glucocorticoidinduced insulin resistance. GLUT4 isoform in rat skeletal muscle is not decreased by dexamethasone. Diabetes 1992, 41:728-735.

44. Kondoh T, Torii K: MSG intake suppresses weight gain, fat deposition, and plasma leptin levels in male Sprague-Dawley rats. Physiol Behav 2008, 95:135-144.

45. Lobato NS, Filgueira FP, Akamine EH, Davel AP, Rossoni LV, Tostes RC, Carvalho $\mathrm{MH}$, Fortes ZB: Obesity induced by neonatal treatment with monosodium glutamate impairs microvascular reactivity in adult rats: role of NO and prostanoids. Nutr Metab Cardiovasc Dis 2011, 21:808-816.

46. Glazier AM, Scott J, Aitman TJ: Molecular basis of the Cd36 chromosomal deletion underlying SHR defects in insulin action and fatty acid metabolism. Mamm Genome 2002, 13:108-113.

47. Chiappe De Cingolani GE, Caldiz Cl: Insulin resistance and GLUT-4 glucose transporter in adipocytes from hypertensive rats. Metabolism 2004, 53:382-387.

48. Han XX, Bonen A: Epinephrine translocates GLUT-4 but inhibits insulinstimulated glucose transport in rat muscle. Am J Physiol 1998, 274:E700-E707.

49. Exton $\mathrm{JH}$ : Mechanisms of hormonal regulation of hepatic glucose metabolism. Diabetes Metab Rev 1987, 3:163-183.

50. Iwase M, Ichikawa K, Tashiro K, lino K, Shinohara N, Ibayashi S, Yoshinari M, Fujishima M: Effects of monosodium glutamate-induced obesity in spontaneously hypertensive rats vs. Wistar Kyoto rats: serum leptin and blood flow to brown adipose tissue. Hypertens Res 2000, 23:503-510.

51. Dandona P, Aljada A, Mohanty P, Ghanim H, Hamouda W, Assian E, Ahmad $S$ : Insulin inhibits intranuclear nuclear factor kappaB and stimulates IkappaB in mononuclear cells in obese subjects: evidence for an antiinflammatory effect? J Clin Endocrinol Metab 2001, 86:3257-3265.

52. Furuya DT, Poletto AC, Favaro RR, Martins JO, Zorn TM, Machado UF: Anti-inflammatory effect of atorvastatin ameliorates insulin resistance in monosodium glutamate-treated obese mice. Metabolism 2010, 59:395-399.

53. Hontecillas R, O'Shea M, Einerhand A, Diguardo M, Bassaganya-Riera J: Activation of PPAR gamma and alpha by punicic acid ameliorates glucose tolerance and suppresses obesity-related inflammation. J Am Coll Nutr 2009, 28:184-195.

54. Gomez Rosso L, Merono T, Benitez MB, Lopez G, Giunta G, D'Ambrosio ML, Wikinski R, Cuniberti L, Brites F: Low adiponectin levels in primary hypertriglyceridemic male patients. Nutr Metab Cardiovasc Dis 2009, 19:135-139.

55. Cassidy A, Skidmore P, Rimm EB, Welch A, Fairweather-Tait S, Skinner J, Burling K, Richards JB, Spector TD, MacGregor AJ: Plasma adiponectin concentrations are associated with body composition and plant-based dietary factors in female twins. J Nutr 2009, 139:353-358.

56. Kouidhi S, Berrhouma R, Rouissi K, Jarboui S, Clerget-Froidevaux MS, Seugnet I, Bchir F, Demeneix B, Guissouma H, Elgaaied AB: Human 
subcutaneous adipose tissue Glut 4 mRNA expression in obesity and type 2 diabetes. Acta Diabetol 2011, Epub ahead of print.

57. Katayama S, Inaba M, Maruno Y, Morita T, Awata T, Oka Y: Glucose intolerance in spontaneously hypertensive and wistar-kyoto rats: enhanced gene expression and synthesis of skeletal muscle glucose transporter 4. Hypertens Res 1997, 20:279-286.

58. Miyata T, Taguchi T, Uehara M, Isami S, Kishikawa H, Kaneko K, Araki E, Shichiri M: Bradykinin potentiates insulin-stimulated glucose uptake and enhances insulin signal through the bradykinin B2 receptor in dog skeletal muscle and rat L6 myoblasts. Eur J Endocrinol 1998, 138:344-352.

59. Carvalho CR, Thirone AC, Gontijo JA, Velloso LA, Saad MJ: Effect of captopril, losartan, and bradykinin on early steps of insulin action. Diabetes 1997, 46:1950-1957.

60. Shepherd P, Kahn B: Glucose transporters and insulin action $\neg$ implications for insulin resistance and diabetes mellitus. N Engl J Med 1999, 341:248-257.

61. Lopaschuk GD, Belke DD, Gamble J, Itoi T, Schonekess BO: Regulation of fatty acid oxidation in the mammalian heart in health and disease. Biochim Biophys Acta 1994, 1213:263-276.

62. Thackeray JT, Radziuk J, Harper ME, Suuronen EJ, Ascah KJ, Beanlands RS, Dasilva JN: Sympathetic nervous dysregulation in the absence of systolic left ventricular dysfunction in a rat model of insulin resistance with hyperglycemia. Cardiovasc Diabetol 2011, 10:75.

63. Luiken JJ, Coort SL, Koonen DP, Bonen A, Glatz JF: Signalling components involved in contraction-inducible substrate uptake into cardiac myocytes. Proc Nutr Soc 2004, 63:251-258.

64. Vettor R, Fabris R, Serra R, Lombardi AM, Tonello C, Granzotto M, Marzolo MO, Carruba MO, Ricquier D, Federspil G, Nisoli E: Changes in FAT/CD36, UCP2, UCP3 and GLUT4 gene expression during lipid infusion in rat skeletal and heart muscle. Int J Obes Relat Metab Disord 2002, 26:838-847.

65. Morel S, Berthonneche C, Tanguy S, Toufektsian MC, Perret P, Ghezzi C, de Leiris J, Boucher F: Early pre-diabetic state alters adaptation of myocardial glucose metabolism during ischemia in rats. Mol Cell Biochem 2005, 272:9-17.

doi:10.1186/1475-2840-11-100

Cite this article as: Leguisamo et al:: GLUT4 content decreases along with insulin resistance and high levels of inflammatory markers in rats with metabolic syndrome. Cardiovascular Diabetology 2012 11:100.

\section{Submit your next manuscript to BioMed Central and take full advantage of:}

- Convenient online submission

- Thorough peer review

- No space constraints or color figure charges

- Immediate publication on acceptance

- Inclusion in PubMed, CAS, Scopus and Google Scholar

- Research which is freely available for redistribution 